\title{
Pengaruh Struktur dan Kultur Organisasi terhadap Keefektifan Partisipasi Anggaran dalam Peningkatan Kinerja Manajerial:Studi Empiris Pada Lembaga Keuangan Syariah
}

\author{
Ginanjar Adi Nugraha*, Aldila Dinanti \\ Universitas Wijayakusuma, Universitas Jenderal Soedirman \\ *andjaradinugraha@gmail.com
}

\begin{abstract}
This study aimed to analyze the influece of budgetary participation on managerial performanc. This study also analyse the effect of organizational structure and culture of the organization on the budget participation in improving managerial performance in the Islamic financial institutions. Research was conducted on Islamic financial institutions in the territory of the former residency of Banyumas with survey method to the manager. The sample was determined by purposive sampling with Non-Probability Sampling Expert method and tested by Moderated Regression Analysis (MIRA). The results of these tests saying that budget participation on the performance of managerial, organizational structural and organizational culture does not moderate the relationship of budget participation and managerial performance.

Keywords: organizational structural, organizational culture, budgetary participation, managerial performance.
\end{abstract}

\begin{abstract}
ABSTRAK
Penelitian ini bertujuan untuk menganalisis pengaruh partisipasi anggaran terhadap kinerja manajerial dan pengaruh struktur organisasi dan kultur organisasi terhadap partisipasi anggaran dalam peningkatan kinerja manajerial di lembaga keuangan syariah. Penelitian ini dilakukan pada lembaga keuangan berbasis syariah di wilayah eks karesidenan Banyumas dengan metode survey terhadap manajer. Sampel dalam penelitian ini ditentukan dengan Non Probability Purposive Sampling dengan metode Expert Sampling dan diuji dengan Moderated Regression Analysis (MIRA). Hasil dari pengujian tersebut mengatakan bahwa partisipasi penyusunan anggaran berpengaruh terhadap kinerja manajerial, struktur organisasi dan kultur organisasi tidak memoderasi hubungan partisipasi anggaran dengan kinerja manajerial.
\end{abstract}

Kata kunci: kultur organisasi, struktur organisasi, partisipasi anggaran, kinerja manajerial.

\section{PENDAHULUAN}

UU Perbankan Syariah no. 21 tahun 2008 menjabarkan bahwa prinsip syariah adalah prinsip hukum Islam dalam kegiatan perbankan berdasarkan fatwa yang dikeluarkan oleh lembaga yang memiliki kewenangan dalam penetapan fatwa di bidang syariah. Prinsip syariah berlandaskan pada nilai-nilai keadilan, kemanfaatan, keseimbangan, dan keuniversalan (rahmatan lil 'alamin). Prinsip 
syariah ini harus dilaksanakan oleh lembaga-lembaga keuangan syariah dalam setiap kegiatannya.

Pada prinsip syariah, Bank Syariah dan UUS wajib menerapkan tata kelola yang baik yang mencakup prinsip transparansi, akuntabilitas,pertanggungjawaban, profesional, dan kewajaran dalam menjalankan kegiatan usahanya.melakukan kerja sama atau tindakan yang sejalan untuk mencapai tujuan bersama dalam mengendalikan Bank (acting in concert) dengan atau tanpa perjanjian tertulis dengan pihak lain.

Suatu proses organisasi yang melibatkan para manajer dalam penentuan tujuan anggaran yang menjadi tanggung jawabnya merupakan partisipasi anggaran (Brownell, 1982). Partisipasi dalam penyusunan anggaran umumnya dinilai sebagai pendekatan manajerial yang dapat meningkatkan kinerja anggota organisasi. Para bawahan yang merasa aspirasinya dihargai dan mempunyai pengaruh pada anggaran yang disusun akan lebih mempunyai tanggung jawab dan konsekuensi moral yang akan meningkatkan kinerja sesuai dengan yang ditargetkan dalam anggaran (Indriantoro, 1998). Partisipasi penyusunan anggaran merupakan pendekatan yang secara umum dapat meningkatkan kinerja yang pada akhirnya dapat meningkatkan efektivitas organisasi. Salah satu faktor yang dapat meningkatkan efektivitas kinerja organisasional adalah kinerja manajerial.

Kinerja manajerial merupakan suatu hasil yang ditunjukkan oleh manajer mengenai prestasi atau kemunduran yang dicapai oleh organisasi (Helfert, 2001). Helfert mengungkapkan pula bahwa kinerja keuangan organisasi merupakan salah satu dasar penilaian kondisi keuangan perusahaan serta perkembangannya. Peningkatan efektivitas kinerja organisasi oleh seorang manajer merupakan suatu kecakapan kinerja manajerial. Kecakapan manajer lahir dari proses panjang melalui proses pengamatan dan belajar. Bukti kemampuan manajer terlihat dari kinerja tim secara optimal sehingga memunculkan dorongan bahwa manajer pada semua tingkatan harus mampu menunjukkan kedekatan secara emosional pada bawahan, dan hubungan tersebut akan memunculkan komitmen kuat pada tim kerjanya.

Struktur organisasi direncanakan dan merupakan usaha yang disengaja untuk menetapkan pola hubungan antara berbagai komponen, sehingga dapat mencapai sasaran secara efektif. Menurut Nadler dan Tushman (1988) dalam Indriantoro (1993) struktur organisasi merupakan alat pengendalian organisasional yang menunjukkan tingkat pendelegasian wewenang manajemen puncak dalam pembuatan keputusan kepada senior manajer dan manajer level menengah. Proses partisipasi memberikan kesempatan bagi bawahan untuk mengajukan pertanyaan kepada atasan

Selain struktur, terdapat transformasi perubahan kultur organisasi yang lebih mempengaruhi organisasi secara hierarkis. Kultur organisasi adalah seperangkat nilai-nilai, keyakinan, dan sikap utama yang diberlakukan di antara 
anggota organisasi (Chuck, 2001). Setiap organisasi memiliki kultur yang mendukung ataupun menghalangi perilaku etis organisasi. Kultur organisasi berhubungan dengan keyakinan umum, praktik, dan sikap karyawan. Sebaik apapun kode etik yang dimiliki perusahaan akan tidak berarti jika ada masalah kultur yang signifikan di dalamnya. Profesionalisme akan dapat dibangun jika tercipta budaya yang kondusif.

Bukti empiris menunjukkan adanya perbedaan pengaruh anggaran partisipatif terhadap peningkatan kinerja manajerial. Brownell dan Icnnes (1983), Nor (2007), Sardjito dan Muthaher (2007), Suardana dan Suryanawa (2009), mengemukakan hubungan yang positif. Tetapi hasil penelitian Supomo dan Indriantoro (1998), Dharma Tintri (2002), dan Sumarno (2005), menemukan hubungan yang negatif.

Berdasarkan penjelasan di atas, riset ini ditunjukan untuk menganalisis apakah partisipasi anggaran berpengaruh terhadap kinerja manajerial serta menganalisis apakah struktur organisasi dan kultur organisasi mempengaruhi partisipasi anggaran dalam peningkatan kinerja manajerial di lembaga keuangan syariah.

\section{TINJAUAN PUSTAKA DAN PENGEMBANGAN HIPOTESIS Pengaruh Partisipasi Anggaran Terhadap Kinerja Manajerial}

Proses penyusunan anggaran suatu organisasi, merupakan kegiatan yang penting dan sekaligus kompleks, karena anggaran mempunyai kemungkinan dampak fungsional atau disfungsional terhadap sikap dan perilaku organisasi (Argyris, 1952; Milani, 1975 dalam Hariyanto, 2008). Brownel (1982) menyebutkan bahwa partisipasi umumnya dinilai sebagai pendekatan manajerial yang dapat meningkatkan kinerja anggota organisasi. Berbagai penelitian yang menguji hubungan antara partisipasi dengan kinerja saling bertentangan. Beberapa penelitian yang mengemukakan pengaruh anggaran partisipatif terhadap kinerja manajerial ditampilkan pada Tabel 1.

Tabel 1. Penelitian Terdahulu yang Menyatakan Terdapat Pengaruh Anggaran Partisipatif Terhadap Kinerja Manajerial

\begin{tabular}{|c|c|c|c|c|}
\hline Tahun & Peneliti & Subjek & Metode & Hasil Penelitian \\
\hline 1983 & $\begin{array}{c}\text { Brownell dan } \\
\text { Icnnes }\end{array}$ & $\begin{array}{c}\text { 224 manajer } \\
\text { menengah dari } \\
\text { berbagai bidang } \\
\text { fungsional pada } \\
\text { perusahaan elektronik } \\
\text { dan industri baja. }\end{array}$ & Kuesioner & $\begin{array}{c}\text { Partisipasi anggaran } \\
\text { berpengaruh positif terhadap } \\
\text { motivasi sehingga } \\
\text { menyebabkan peningkatan } \\
\text { kinerja yang lebih tinggi. }\end{array}$ \\
\hline 2007 & $\begin{array}{c}\text { Sardjito dan } \\
\text { Muthaher }\end{array}$ & $\begin{array}{c}\text { Pejabat di Kantor } \\
\text { Pemkot dan Pemda } \\
\text { Semarang. }\end{array}$ & Kuesioner & $\begin{array}{c}\text { Penyusunan anggaran } \\
\text { partisipatif berpengaruh } \\
\text { signifikan terhadap kinerja } \\
\text { aparat pemerintah daerah. }\end{array}$ \\
\hline
\end{tabular}


Lanjutan Tabel 1. Penelitian Terdahulu yang Menyatakan Terdapat Pengaruh Anggaran Partisipatif Terhadap Kinerja Manajerial

\begin{tabular}{|c|c|c|c|c|}
\hline Tahun & Peneliti & Subjek & Metode & Hasil Penelitian \\
\hline 2007 & Nor & $\begin{array}{l}\text { Manajer/kepala unit } \\
\text { organisasi hybrid. }\end{array}$ & Kuesioner & $\begin{array}{l}\text { Tinggi rendahnya tingkat } \\
\text { kesesuaian antara partisipasi } \\
\text { penyusunan anggaran } \\
\text { dengan desentralisasi tidak } \\
\text { berpengaruh terhadap tinggi } \\
\text { rendahnya kinerja } \\
\text { manajerial; tingkat } \\
\text { kesesuaian partisipasi } \\
\text { penyusunan anggaran } \\
\text { dengan gaya kepemimpinan } \\
\text { tidak berpengaruh dengan } \\
\text { tinggi rendahnya kinerja } \\
\text { manajerial. }\end{array}$ \\
\hline 2009 & $\begin{array}{l}\text { Suardana dan } \\
\text { Suryanawa }\end{array}$ & $\begin{array}{l}\text { Kepala dinas, kepala } \\
\text { subdinas /kepala } \\
\text { bagian/ kepala bidang, } \\
\text { dan kepala subbagian/ } \\
\text { kepala subbidang/ } \\
\text { kepala seksi dari } \\
\text { dinas-dinas di } \\
\text { Kabupaten Badung. }\end{array}$ & Kuesioner & $\begin{array}{l}\text { Partisipasi penyusunan } \\
\text { anggaran berpengaruh } \\
\text { positif dan signifikan } \\
\text { terhadap kinerja manajerial. }\end{array}$ \\
\hline
\end{tabular}

Tetapi hasil penelitian yang dilakukan oleh beberapa peneliti lain menemukan bahwa tidak terdapat hubungan antara anggaran partisipatif dengan kinerja manajerial. Hasil penelitian - penelitian tersebut dapat dilihat pada Tabel 2.

Tabel 2. Penelitian Terdahulu yang Menyatakan Tidak Terdapat Pengaruh Anggaran Partisipatif Terhadap Kinerja Manajerial

\begin{tabular}{|c|c|c|c|c|}
\hline Tahun & Peneliti & Subjek & Metode & Hasil Penelitian \\
\hline 1998 & $\begin{array}{c}\text { Supomo dan } \\
\text { Indriantoro }\end{array}$ & $\begin{array}{c}79 \text { manajer dari } \\
\text { perusahaan } \\
\text { manufaktur. }\end{array}$ & Kuesioner & $\begin{array}{c}\text { Partisipasi yang tinggi } \\
\text { dalam penyusunan anggaran } \\
\text { tidak meningkatkan kinerja } \\
\text { manajerial. }\end{array}$ \\
\hline 2002 & Tintri & $\begin{array}{c}53 \text { manajer yang } \\
\text { memimpin departemen } \\
\text { fungsional (heterogen) } \\
\text { dari emiten-emiten } \\
\text { melalui BEJ. }\end{array}$ & Kuesioner & $\begin{array}{c}\text { Partisipasi yang tinggi } \\
\text { dalam penyusunan anggaran } \\
\text { berpengaruh negatif dalam } \\
\text { peningkatan kinerja } \\
\text { manajerial. }\end{array}$ \\
\hline 2005 & Sumarno & $\begin{array}{c}90 \text { manajer kantor } \\
\text { cabang utama bank- } \\
\text { bank di Jakarta. }\end{array}$ & Kuesioner & $\begin{array}{c}\text { Kinerja manajerial dan } \\
\text { partisipasi anggaran } \\
\text { memiliki hubungan negatif. }\end{array}$ \\
\hline 2008 & Hariyanto & $\begin{array}{c}150 \text { manajer level } \\
\text { menengah di BUMN }\end{array}$ & Kuesioner & $\begin{array}{c}\text { Penganggaran partisipatif } \\
\text { tidak berpengaruh terhadap } \\
\text { kinerja manajer. }\end{array}$ \\
\hline
\end{tabular}

Atas adanya perbedaan beberapa hasil penelitian yang dilakukan tersebut, maka hipotesis yang diajukan adalah sebagai berikut.

H1: Partisipasi anggaran berpengaruh positif terhadap kinerja manajerial. 


\section{Pengaruh Struktur Organisasi Terhadap Partisipasi Anggaran}

Proses partisipasi memberikan kesempatan bagi bawahan untuk mengajukan pertanyaan kepada atasan. Dengan mengajukan pertanyaan maupun minta penjelasan, bawahan dapat memperoleh informasi yang lebih baik tentang tugas dan strategi penyelesaiannya. Penerimaan pengetahuan yang berhubungan dengan tugas dapat meningkatkan kinerja.

Struktur organisasi merupakan alat pengendalian organisasional yang menunjukkan tingkat pendelegasian wewenang manajemen puncak dalam pembuatan keputusan kepada senior manajer dan manajer level menengah. Namun bagi manajer,kepemimpinan merupakan bagian dari sikap karena kepemimpinan dapat dipelajari serta dipengaruhi oleh faktor internal, seperti kapabilitas perusahaan, ukuran perusahaan, struktur organisasi dan sebagainya (Zhang, 2000). Dengan adanya struktur organisasi, maka stabilitas dan kelangsungan organisasi tetap bertahan.

Menurut Gibson (1987) terdapat tiga faktor yang berpengaruh terhadap kinerja, yaitu: (1) faktor individu yang meliputi kemampuan, ketrampilan, latar belakang keluarga, pengalaman kerja, tingkat sosial dan demografi seseorang; (2) faktor psikologis yang meliputi persepsi, peran, sikap, kepribadian, motivasi dan kepuasan kerja; (3) faktor organisasi yang meliputi struktur organisasi, kultur, desain pekerjaan, kepemimpinan, dan sistem penghargaan (reward system).

Fali Suaedi (2005) dalam penelitiannya mengatakan bahwa struktur organisasi berpengaruh langsung positif signifikan terhadap kinerjaorganisasi.Struktur organisasi pada hotel bintang tiga di Jawa Timur, lebihmenunjukkan struktur yang organis yaitu struktur yang rendah spesialisasi,rendah formalisasi, rentang kendali yang longgar, desentralisasi, adanya timsilang fungsional dan distribusi informasi yang merata mampu mendorongberkembangnya dinamika dalam lingkungan kerja, semangat kerja danproduktivitas kerja. Salah satu yang terdapat dalam struktur yang organisadalah adanya tim lintas fungsional.

Hasil penelitian yang dilakukan oleh Supomo dan Indriantoro (1998) dan Tintri (2002) menyatakan bahwa partisipasi yang tinggi dalam penyusunan anggaran akan mempunyai pengaruh positif terhadap kinerja manajerial pada struktur desentralisasi, dan mempunyai pengaruh negatif pada struktur sentralisasi. Maka hipotesis yang diajukan adalah

H2: Struktur organisasi (desentralisasi atau sentralisasi) mempengaruhi partisipasi anggaran dalam peningkatan kinerja manajerial.

\section{Pengaruh Kultur Organisasi Terhadap Partisipasi Anggaran}

Hofstede (1994) dalam Tintri (2002) menyatakan bahwa kultur merupakan keseluruhan pola pemikiran, perasaan dan tindakan dari suatu kelompok sosial yang lain. Kultur dapat diklasifikasikan dalam berbagai tingkatan, antara lain 
nasional, daerah, gender, generasi, kelas sosial, organisasional perusahaan. Pada tingkat organisasi, kultur merupakan seperangkat asumsi-asumsi, keyakinankeyakinan, yang berorientasi pada orang dan yang berorientasi pada pekerjaan. Anggaran yang partisipatif lebih mencerminkan bahwa keputusan-keputusan yang penting dalam proses penyusunan anggaran dibuat secara kelompok daripada dibuat secara individual. Menurut Hofstede, dkk. (1990), pembuatan keputusan secara kelompok merupaka karakteristik yang menonjol dari dimensi kultur yang berorientasi pada orang. Partisipasi umumnya diterima sebagai penerapan pemikiran 'human relations' dalam penyusunan anggaran (Argys, 1952). Partisipasi dalam penyusunan anggaran kemungkinan akan lebih efektif pada kultur organisaisonal yang berorientasi pada orang daripada kultur organisasional yang berorientasi pada tugas.

Kultur organisasi berhubungan dengan keyakinan umum, praktik, dan sikap karyawan. Kultur yang mampu menyesuaikan dan mendorong keterlibatan karyawan, dapat memperjelas tujuan dan arah strategis organisasi, serta yang senantiasa menguraikan dan mengajarkan nilai-nilai dan keyakinan organisasi, dapat membantu perusahaan mencapai pertumbuhan penjualan, pengembalian modal, keuntungan, mutu, dan kepuasan pelanggan yang lebih tinggi. Profesionalisme akan dapat dibangun jika tercipta budaya yang kondusif. Dalam kultur organisasi yang konsisten, organisasi dengan aktif menguraikan dan mengajarkan nilai-nilai, keyakinan, dan sikap organisasi.

Suaedi (2005) melakukan penelitian pada seluruh karyawan yang bekerja pada 20 hotel bintang tiga di Jawa timur dalam penelitiannya mengatakan bahwa kultur organisasi berpengaruh langsung positif signifikan terhadap kinerjaorganisasi. Budaya organisasi pada organisasi hotel bintang tiga di JawaTimur, lebih mencerminkan dan memberi ruang pada terjadinya perubahan, dengan demikian lebih mudah beradaptasi terhadap dinamika lingkungan dan budaya yang mendorong terjadinya proses pembelajaran sehingga mampumendukung kinerja organisasi.

Hasil penelitian yang dilakukan oleh Supomo dan Indriantoro (1998) dan Tintri (2002) menyatakan bahwa kultur organisasional yang berorientasi pada orang mempunyai pengaruh positif terhadap hubungan antara partisipasi dengan kinerja manajerial dan kultur organisasional yang berorientasi pada pekerjaan mempunyai pengaruh positif terhadap hubungan antara partisipasi dengan kinerja manajerial; Sardjito dan Muthaher (2007) menyatakan dalam penelitiannya bahwa terdapat pengaruh yang signifikan antara variabel kultur organisasi dalam memoderasi partisipasi penyusunan anggaran dengan kinerja manajerial. Semakin tinggi tingkat kesesuaian antara partisipasi penyusunan anggaran dan budaya organisasi yang berorientasi pada orang akan semakin tinggi kinerja aparat pemerintah daerah(kabag/kasub). Maka hipotesis yang diajukan adalah 


\section{H3: Kultur organisasi berpengaruh terhadap hubunganpartisipasi anggaran dengan kinerja manajerial.}

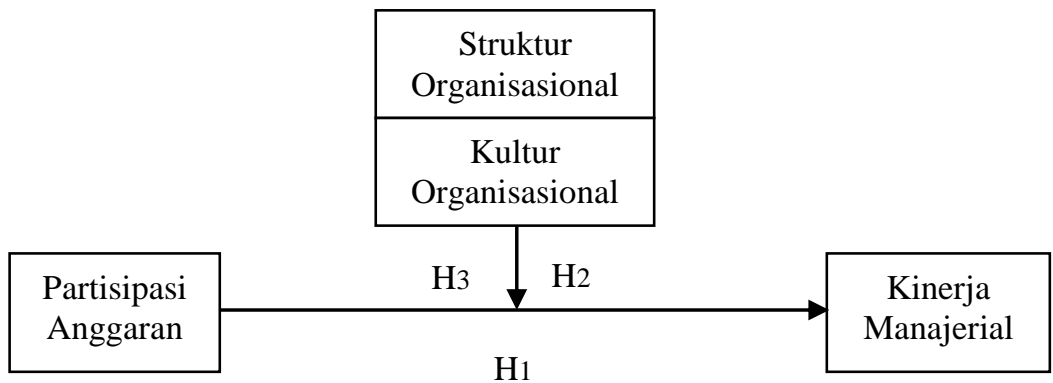

Gambar 1. Model Penelitian

\section{METODE PENELITIAN}

Penelitian ini merupakan studi empiris menggunakan metode survey terhadap manajer pada lembaga keuangan syariah dalam memperoleh data. Pada pengumpulan data dilakukan wawancara, yaitu dengan tanya jawab langsung kepada pihak terkait serta kuesioner, yaitu pengambilan data dengan cara menyusun daftar pertanyaan yang berisi tanggapan karyawan yang dijadikan responden. Populasi dalam penelitian ini adalah manajer dan setingkat manajer LKS di wilayah Karesidenan Banyumas. Sampel dalam penelitian ini ditentukan dengan metode non probability purposive sampling dengan metode expert sampling.

Metode analisis yang digunakan yakni uji validitas, reliabilitas, dan uji normalitas. Uji normalitas menggunakan uji statistik non-parametrik Kolmogorov-Smirnov, yakni merupakan uji normalitas menggunakan fungsi distribusi kumulatif. Nilai residual terstandarisasi berdistribusi normal jika $\mathrm{K}$ hitung < K tabel atau nilai Sig. > alpha. Uji Hipotesis Analisis Regresi Variabel Moderasi dengan Metode Interaksi. Uji interaksi sering juga disebut dengan Moderated Regression Analysis (MRA). Pada uji interaksi model persamaan regresi diformulasikan sebagai berikut:

$$
\mathrm{Y}=\mathrm{a}+\mathrm{b} 1 \mathrm{X} 1+\mathrm{b} 2 \mathrm{X} 2+\mathrm{b} 3 \mathrm{X} 3+\mathrm{b} 4 \mathrm{X} 1 \mathrm{X} 2+\mathrm{b} 5 \mathrm{X} 1 \mathrm{X} 3+\mathrm{b} 6 \mathrm{X} 2 \mathrm{X} 3+\mathrm{b} 7 \mathrm{X} 1 \mathrm{X} 2 \mathrm{X} 3+\mathrm{e}
$$

Keterangan:

$\mathrm{Y}=$ Kinerja Manajerial

$\mathrm{X} 1=$ Partisipasi Anggaran

$\mathrm{X} 2$ = Struktur Organisasi

X3 = Kultur Organisasi

\section{HASIL PENGUJIAN HIPOTESIS}

Responden yang dapat dijadikan sampel dalam penelitian ini adalah manajer utama atau pimpinan puncak dan manajer tingkat 1 sampai dengan 2 
dibawah manajer utama. Hal ini dilakukan dengan pertimbangan bahwa manajer memiliki persepsi yang berbeda tentang partisipasi anggaran, sehingga persepsi dari masing-masing manajer lebih bervariasi (Gul dkk., 1995). Sampel dalam penelitian ini ditentukan dengan Non Probability Purposive Sampling dengan metode Expert Sampling yaitu para ahli memang menjadi tujuan untuk menjadi anggota sampel.

Hasil uji validitas dengan metode korelasi product moment pearson diperoleh hasil valid. Hasil dari uji reliabilitas menjelaskan bahwa pernyataan pada instrumen partisipasi anggaran nilai $r$ tabel adalah sebesar 0,339 dengan nilai r hitung 0,979; variabel struktur organisasi dengan $r$ hitung 0,897 ; dan variabel kultur organisasi dengan $r$ hitung 0.381 , dan kinerja manajerial dengan $r$ hitung 0,840. Sehingga dapat disimpulkan bahwa keempat instrumen tersebut reliabel. Uji normalitas menggunakan uji statistik non-parametrik Kolmogorov-Smirnov. Nilai residual terstandarisasi berdistribusi normal jika $\mathrm{K}$ hitung $<\mathrm{K}$ tabel atau nilai Sig. > alpha. Berdasarkan uji normalitas nilai Sig. (2-tailed) sebesar 0,315> 0,05 maka nilai residual terstandarisasi dapat dikatakan berdistribusi normal.

Uji interaksi sering juga disebut Moderated Regression Analysis (MRA) dilakukan dengan mengalikan variabel yang dihipotesiskan sebagai variabel moderasi dengan variabel bebas. Jika variabel hasil perkalian antara variabel bebas dengan variabel yang dihipotesiskan sebagai variabel moderasi signifikan maka dapat disimpulkan bahwa variabel yang dihipotesiskan sebagai variabel moderasi benar-benar memoderasi hubungan antara variabel bebas dengan variabel tergantungnya (Suliyanto, 2011).

Berdasarkan output persamaan regresi pertama, koefisien regresi partisipasi anggaran sebesar 0,140 dengan t hitung 2,305. Sedangkan nilai $p$ value 0,033 yang artinya variabel partisipasi anggaran berpengaruh terhadap variabel kinerja manajerial.

Pada persamaan regresi kedua diperoleh koefisien regresi partisipasi anggaran 0,167 dengan thitung 1,900 sedangkan $p$ value 0,033, maka partisipasi anggaran berpengaruh terhadap kinerja manajerial. Koefisien regresi struktur organisasi -0,032 dengan $t_{\text {hitung }}-0,395$ sedangkan $p$ value 0,348 , maka struktur organisasi tidak berpengaruh terhadap kinerja manajerial. Koefisien regresikultur organisasi 0,049 dengan thitung 0,270 sedangkan sig 0,394, maka kultur organisasi tidak berpengaruh terhadap kinerja manajerial.

Pada persamaan regresi ketiga diperoleh bahwa koefisien regresi partisipasi anggaran 1,798 dengan $t_{\text {hitung }}$ 1,455 sedangkan sig 0,156, maka partisipasi anggaran tidak berpengaruh terhadap kinerja manajerial. Koefisien regresistruktur organisasi $-0,909$ dengan $t_{\text {hitung }}-0,770$ sedangkan sig 0,447 , maka struktur organisasi tidak berpengaruh terhadap kinerja manajerial. Koefisien regresi kultur organisasi sebesar 0,648 dengan thitung sebesar 0,349 sedangkan sig -0,729, maka kultur organisasitidak berpengaruh terhadap kinerja manajerial. 
Koefisien regresi variable interaksi struktur organisasi dan partisipasi anggaran 0,001 dengan $t_{\text {hitung }}$ 0,022 sedangkan sig 0,982, maka variabel interaksi struktur organisasi dengan partisipasi anggaran tidak berpengaruh terhadap kinerja manajerial.

Koefisien regresi interaksi kultur organisasi dan partisipasi anggaran 0,085 dengan $t_{\text {hitung }}-1,272$ sedangkan sig 0,213, maka variabel interaksi struktur organisasi dengan partisipasi anggaran tidak berpengaruh terhadap kinerja manajerial. Koefisien regresi interaksi struktur organisasi dan kultur organisasi 0,064 dengan $t_{\text {hitung }}$ 1,012 sedangkan sig 0,320, maka interaksi struktur organisasi dengan kultur organisasi tidak berpengaruh terhadap kinerja manajerial. Koefisien regresi interaksi partisipasi anggaran, struktur organisasi dan kultur organisasi -0,000 dengan $t_{\text {hitung }}-0.1942$ sedangkan sig 0.848 , maka interaksi partisipasi anggaran, struktur organisasi dan partisipasi anggaran tidak berpengaruh terhadap kinerja manajerial.

Pengujian Hipotesis Pertama diketahui sig 0,660 dan p value 0,033, maka disimpulkan bahwa partisipasi anggaranberpengaruh positif terhadap kinerja manajerial.

Pengujian Hipotesis Kedua didapati sig 0,982. Hal ini berarti bahwa variabel struktur organisasi tidak berpengaruh terhadap hubungan partisipasi aggarandengankinerja manajerial, sehingga hipotesis ditolak. Struktur organisasi tidak memoderasi hubungan antara partisipasi anggaran dengankinerja manajerial, sehingga hipotesis keduaditolak. Hal tersebut mengartikan bahwa struktur desentralisasi pada organisasi lembaga keuangan syariah tidak memiliki pengaruh moderating terhadap hubungan antara partisipasi anggaran dan peningkatan kinerja manajerial namun berpengaruh pada struktur sentralisasi.

Pengujian Hipotesis Ketigadidapati sig 0,213, maka variabel kultur organisasi tidak berpengaruh terhadap hubungan partisipasi anggaran terhadapkinerja manajerial, sehingga hipotesis ditolak. Kultur organisasi tidak memoderasi hubungan antara partisipasi anggarandengan kinerja manajerial sehingga hipotesis ketiga ditolak. Hal tersebut mengartikan bahwa kultur yang berorientasi pada orang dalam organisasi lembaga keuangan syariah tidak memiliki pengaruh moderating terhadap hubungan antara partisipasi anggaran dan peningkatan kinerja manajerial namun tidak berpengaruh pada kultur organisasi yang berorientasi pada pekerjaan.

\section{KESIMPULAN, KETERBATASAN DAN SARAN \\ Pengaruh Partisipasi Anggaran Terhadap Kinerja Manajerial}

Proses penyusunan anggaran suatu organisasi, merupakan kegiatan yang penting dan sekaligus kompleks, karena anggaran mempunyai kemungkinan dampak fungsional atau disfungsional terhadap sikap dan perilaku organisasi (Argyris, 1952; Milani, 1975 dalam Hariyanto, 2008). Brownel (1982) 
menyebutkan bahwa partisipasi umumnya dinilai sebagai pendekatan manajerial yang dapat meningkatkan kinerja anggota organisasi.Partisipasi anggaranberpengaruh terhadap kinerja manajerial. Hasil dalam penelitian ini mendukung hasil penelitian yang diperoleh Brownell dan Icnnes (1983), Nor (2007), Sardjito dan Muthaher (2007)yang mengemukakan bahwa anggaran partisipatif berhubungan positif terhadap kinerja manajerial.

\section{Struktur Organisasi Berpengaruh Terhadap Hubungan Partisipasi Anggaran dengan Kinerja Manajerial.}

Menurut Gibson (1987) terdapat tiga faktor yang berpengaruh terhadap kinerja, yaitu: (1) faktor individu yang meliputi kemampuan, ketrampilan, latar belakang keluarga, pengalaman kerja, tingkat sosial dan demografi seseorang; (2) faktor psikologis yang meliputi persepsi, peran, sikap, kepribadian, motivasi dan kepuasan kerja; (3) faktor organisasi yang meliputi struktur organisasi, kultur, desain pekerjaan, kepemimpinan, dan sistem penghargaan (reward system).

Struktur organisasi tidak berpengaruh terhadap hubungan partisipasi penyusunan anggaran dengan kinerja manajerial. Hasil dalam penelitian ini tidak mendukung hasil penelitian yang diperoleh Supomo dan Indriantoro (1998), Tintri (2002), Sardjito dan Muthaher (2007), Suardana dan Suryanawa (2009) mengemukakan bahwa struktur sebagai alat pengendalian suatu organisasi.

Dalam hal ini struktur organisasi tidak memiliki pengaruh terhadap partisipasi anggaran.Struktur desentralisasi pada organisasi lembaga keuangan syariah tidak memiliki pengaruh moderating terhadap hubungan antara partisipasi anggaran dan peningkatan kinerja manajerial namun berpengaruh pada struktur sentralisasi. Tinggi rendahnya proses partisipasi dalam memberikan kesempatan bagi bawahan untuk mengajukan bernagai macam pertanyaan kepada atasan dimana dengan mengajukan pertanyaan maupun penjelasan kepada atasan, bawahan dapat memperoleh informasi yang lebih baik tentang tugas dan strategi penyelesaiannya tidak akan mempengaruhi hubungan antara partisipasi anggaran terhadap kinerja manajerial. Penerimaan pengetahuan yang diterima bawahan tersebut akan berhubungan dengan tugas tidak akan berakibat dapat meningkatkan kinerja.

\section{Kultur Organisasi Berpengaruh Terhadap Hubungan Partisipasi Anggaran dengan Kinerja Manajerial.}

Kultur organisasi tidak berpengaruh terhadappartisipasi penyusunan anggaran. Hasil dalam penelitian ini tidak mendukung hasil penelitian yang diperoleh Supomo dan Indriantoro (1998), Tintri (2002), Sardjito dan Muthaher (2007), Suardana dan Suryanawa (2009), yang mengemukakan bahwa struktur sebagai alat pengendalian suatu organisasi dan kultur sebuah organisasi yang 
merupakan seperangkat nilai-nilai, keyakinan, dan sikap utama berhubungan positif terhadap kinerja manajerial dan kepuasan kerja.

Semakin baik kultur yang melekat tidak akan meningkatkan partisipasi dalam penyusunan anggaran. Dalam hal ini kultur yang berorientasi pada orang dalam organisasi lembaga keuangan syariah tidak memiliki pengaruh moderating terhadap hubungan antara partisipasi anggaran dengan peningkatan kinerja manajerial namun berpengaruh pada kultur organisasi yang berorientasi pada pekerjaan.

Faktor kultur organisasi kemungkinan menjadi faktor kondisional yang harus dipertimbangkan dalam rangka peningkatan efektivitas organsasi melalui partisipasi penyusunan anggaran. Faktor tersebut penting dalam kondisi era globalisasi yang penuh dengan ketidakpastian lingkungan.

Kesimpulan dari penelitian ini adalah partisipasi penyusunan anggaran berpengaruh terhadap kinerja manajerial, struktur organisasi tidakmemoderasi hubunganpartisipasi anggaran dengan kinerja manajerial, serta kultur organisasitidak memoderasi hubungan partisipasi anggaran terhadap kinerja manajerial.

Penelitian selanjutnya diharapkan dapat mengembangkan dan mengukur pengaruh struktur organisasi dengan partisipasi anggaran, dan pengaruh kultur organisasi dengan partisipasi anggaran, serta mempertimbangkan penggunaan variabel moderasi atau pun variabellain, misalnya gaya kepemimpinan, budaya paternalistik, dan sebagainya.

\section{REFERENCES}

Argyris. 1952. Organizational Leadership and Participation Management. The Journal of Business, 28(1): 1-7.

Supomo, N. dan Indriantoro, N. 1998. Pengaruh Struktur dan Kultur Organisasional Terhadap Keefektifan Anggaran Partisipatif Dalam Peningkatan Kinerja Manajerial: Studi Empiris pada Perusahaan Manufaktur Indonesia. Jurnal KELOLA, 7(18): 61-85.

Brownell, P. 198. Participation in Budgeting Locus of Control and Organizational Effectiveness. The Accounting Review, 56(4): 844-860. http://www.jstor.org/stable/247205.

1985). Participation In The Budgeting Process When It Works and When It Doesnt. Journal of Accounting Research, 23(2): 502-512. http://www.jstor.org/stable/2490823.

(1982). The Role of Accounting Data in Performance Evaluation, Budgetary Participation, and Organizational Effectiveness. Journal of Accounting Research, 20(1): 12-27. 
dan Icnnes, M. 1983. Budgetary Participation, Motivation and Managerial Performance. The Accounting Review. 61(4): 587-600.

Gibson, dkk. 1987. Organisasi : Perilaku, Struktur, Proses, Edisi Kelima, Jilid 1, Alih Bahasa Djarkasih. Jakarta: Erlangga.

Hariyanto, Eko. 2008. Penganggaran Partisipatif Sebagai Motivasi Kinerja Manajer. Universitas Jenderal Soedirman. http://download.portalgaruda.org/article.php?article=14090\&val=945

Indriantoro, Nur. 1993. The Effect of Participative Budgeting on Job Perfor mance and Job satisfaction with Locus of Control and Cultural Dimensions ad Moderating Variables. Ph.D. Dissertation, University of Kentucky, Lexington.

J. Sumarno. 2005. Pengaruh Komitmen Organisasi dan Gaya Kepeimpinan Terhadap Hubungan Antara Partisipasi Anggaran dan Kinerja Manajerial. Simposium Nasional Akuntansi VIII, Solo, Indonesia: 588616.

Kenis, I. 1979. Effects of Budgetary Goal Characteristics on Managerial Attitudes and Performance”. The Accounting Review, Vol. 54(4): 707-721. http://www.jstor.org.

Milani. 1975. The Relationship of Participation in Budget Setting to Industrial Supervisor Performance and Attitudes: A Field Study. The Accounting Review, Vol. 50(2): 274-284.

Nor, Wahyudin. 2007. Desentralisasi Dan Gaya Kepemimpinan Sebagai Variabel Moderating Dalam Hubungan Antara Partisipasi Penyusunan Anggaran dan Kinerja Manajerial. Simposium Nasional Akuntansi X, Makassar, Indonesia: 1-27.

Sardjito, Bambang dan Osmad Muthaher. 2007. Pengaruh Partisipasi Penyusunan Anggaran Terhadap Kinerja Aparat Pemerintah Daerah: Budaya Organisasi dan Komitmen Organisasi sebagai Variabel Moderating. Simposium Nasional Akuntansi X, Makassar, Indonesia: $1-27$.

Suliyanto. 2011. Ekonometrika Terapan: Teori \& Aplikasi dengan SPSS. Yogyakarta: CV Andi Offset.

Suryanto. 2009. Merancang dan menetapkan tujuan organisasi. (online), http://suryanto.blog.unair.ac.id/2009/02/11/merancang dan menetapkan tujuan organisasi. 
Kompartemen: Jurnal Ilmiah Akuntansi/Maret 2018, XVI(1), 21-33

Tintri, Dharma. 2002. Pengaruh Struktur dan Kultur Organisasional Terhadap Keefektifan Anggaran Partisipatif Dalam Peningkatan Kinerja Manajerial. Jurnal Ekonomi dan Bisnis, Vol. 2(7): 59-68.

Williams, Chuck. 2001. Manajemen. Edisi Pertama. Jakarta: Salemba Empat.

Yusfaningrum, Kusnasriyanti dan Imam Ghozali. 2005. Analisis Pengaruh Partisipasi Anggaran Terhadap Kinerja Manajerial Melalui Komitmen Tujuan Anggaran Dan Job Relevant Information (JRI) Sebagai Variabel Intervening (Penelitian Terhadap Perusahaan Manufaktur Di Indonesia). Simposium Nasional Akuntansi VIII, Solo, Indonesia: 656666.

Zhang, Euan Wu. 2000. The Sustainability Balanced Scorecard Linking Sustainability Management to Bussiness Strategy. 